\title{
Squaring Youth Ambition and Old Generation Commitment in Tunji Ogundimu's Pensioners and Prisoners
}

\author{
Yélian Constant Aguessy, \\ Université de Parakou, Bénin
}

Doi:10.19044/esj.2019.v15n26p109 URL:http://dx.doi.org/10.19044/esj.2019.v15n26p109

\begin{abstract}
The unfailing role of the old generation is to advise and orient the youth to avoid taking immature decisions. In this respect, the current paper aims to show how the old generation raises in the youth the interest to stay in their countries and stop the brain drain to the Western countries, which affects the development of the African nations. In effect, the study has been conducted through Tunji Ogundimu's Pensioners and Prisoners where Pa Joshua, the round protagonist has strongly opposed and rejected the inordinate ambition of his son Bola to migrate to USA so as to work and make fortune to reduce the plight of the family. For him there is no better place than home. It is on this way that he invites the youth of his country to stand up for the fight and not give up the fight and face the reality of unemployment and precariousness of living conditions. This paper makes it clear that the youth are immature and inexperienced. As argued here the elders must serve as model that the youth have to consult. Further, the paper has proved that the labour force must stop fleeing the African countries to the Western ones. Eventually, the study has revealed that the passive and active masses have to unite to stop bad governance.
\end{abstract}

Keywords: Old generation, youth commitment, unemployment, plight, migration

\section{Introduction}

Every human being is committed to a struggle of continuous or dayto-day search for better working and living conditions. "People in poverty go through each day with the will to survive" said the Director-General of the International Labour Office in Geneva in his report of the $91^{\text {st }}$ International Labour Conference. So, In this social context, many people are sent to school and craft industries so as to be trained to acquire knowledge in specific domains, to become professionals, have a good job and then earn secure and 
enviable living conditions. In this useful struggle, young people show their eagerness to win the battle. Anything which is available and that can be made use of to achieve their goal is picked up and used without reservation; including migrating to another country, region or even continent. Sometimes this youth's ambition coupled with the old generation's serious-minded commitment and experience give birth to a path of success. Tunji Ogundimu, in his novel Pensioners and Prisoners, has depicted this reality through some of his characters, mainly $\mathrm{Pa}$ Joshua the father and Bola the son. Bola's aspiration to migrate to earn a better living condition is manifest and $\mathrm{Pa}$ Joshua's experience and commitment has helped control Bola's ambition and eventually Bola has reached his goal. Pensioners helped by the youth impeach Governor Awawi and free their social class from precarious living condition they experience.

This article aims to show that brain drain is not the last resort for youth in the process of solving precariousness of living condition. The current paper intends to show how useful it is, for young and old generations, to get connected in the battle against a starving government and finally to demonstrate the necessity of individual's commitment in the aforementioned process.

To achieve the goal of the research, both quantitative and qualitative research methodologies are adopted and the 'Marxism' literary theory is used because of social class struggle which clearly states the demarcation between the 'the haves' and 'have nots.' In fact, Fidel Castro a Cuban Marxist-Leninist politician confessed the following in an interview.

Marxism taught me what society was. I was like a blindfolded man in a forest, who does not even know where north or south is. If you don't eventually come to understand the history of the class struggle, or at least have a clear idea that society is divided between the rich and the poor, and that some people subjugate and exploit other people, you are lost in a forest, not knowing anything. (Castro 2009)

Through this declaration by Fidel, it is clear that Marxist theory reveals a distinction between the rich and the poor. This demarcation in the actual lifestyles of the two classes is one of the main factors that favour brain drain simply because the subjugated class ventures into the quest for its emancipation. The term emancipation is what is most highlighted in the definition of Marxism suggested by Wikipedia: "Marxism is a theory and method of working-class self-emancipation". The concept "selfemancipation" shows that there is a need for struggle. The subjugated class has to rise up and find ways and means to remove the yoke put on it. Consequently, this theory is deemed adequate to the issue of brain drain this paper raises. 
Moreover, this paper is decrypted into three different parts. Firstly, the favourable environment available for brain drain is discussed. The second part goes over the connection between old and young generations, its importance and outcomes. The third one considers commitment a sine qua non condition to win the battle of better living condition.

\section{Environment Favouring Brain-drain.}

One of the most growing phenomena in Africa during the recent decades is brain drain of the youth. "The African Union estimates that about 70,000 skilled professionals emigrate from Africa every year" (Kweitsu, 2018). Consequently, that field of research has caught the attention of many scholars. Those scholars have tried to work on almost all its different aspects. They all tried to give a clarification to the term. First of all, many of them agreed on the fact that brain drain is a recurrent, common, and growing phenomenon. In the report of the workshop of 2006 "The Brain Drain: What Do We Know?", organised by Agence Française de Développement, it is pointed out that:

Brain drain has been increasing worldwide in absolute figures. The number of high-skilled international migrants climbed from 16.4 million in 1990 to 26.2 million in 2000 , which implies an annual growth rate of 4.8 per cent. Between 2000 and 2010, the emigration of highly educated persons continued to increase, rising at an estimated annual pace of 4 per cent (based on figures for the United States, the largest destination for brain drain worldwide and home to some 40 per cent of all high-skilled emigrants)

(Docquier, 2006:5).

Through the analysis of these figures, they show that during the last three decades, brain drain is increasing extensively. Some figures show that Africa, as a continent, pushes out a great number of these migrants. In their article "The Quality of Governance: Second Generation Civil Reform in Africa" Haque and Jahangir write that the number of highly skilled emigrants from Africa increased from 1,800 a year on average during the period 196075 to 4,400 during 1975-84 and 23,000 during 1984-87 (1999:65-106). Ogbuagu Buster and Baffoe, Michael based on a census carried out in the North America, reported that

"In 2001, Census Canada reported that 30 percent of the Black Community in Canada was under the age of 25, compared to only 19 percent for the general population. By contrast, only 5 percent of the Black population was aged 65 or over in 2001 , representing less than half the proportion of 12 percent for the General Canadian population" (Ogbuagu and Baffoe, 2015). 
This state of affair cannot help the economic growth and the economic development, for Africa assists passively to the exodus of her young, valid and skilled labour force to West

What then is Brain Drain? Also known as high-skilled migration or "High Skill Migration" (HSM) according to (David Hart, 2006), brain drain is the migration of persons with increased levels of skill and education who, if they stayed could contribute significantly to the development of the country (Hart 2006). So, there are different kinds of migration in terms of duration, objective, kind of migrants, and area of migration and so on. Hart explains that this migration concerns well-educated people; persons with a considerable knowledge acquisition who can put their knowledge at the disposal of their country to favour its development on a large scale. While trying to make the difference between general migration and HSM, it is discovered that the only one difference between the two is that in the HSM the migrants move with human capital skill and expertise (Grubel and Scott 1977).

As for Dugger, those who vacate their country to move to another one happen to be educators, health care workers, scientists, engineers, professors and political reformers (Dugger 2005). Every country needs the contribution of all its citizens and especially trained people and expert. This is the trend that links the above conception and the one by Grubel. From these two ideas, it appears that brain drain is the movement of the major pillars of the development of a country by those from a given country in quest of happiness.

In Ogundimu's Pensioners and Prisoners, Bola is revealed with a strong determination of travelling to the United States of America (USA). He is so eager to fly there that he is ready to disobey his father, Pa Joshua. In this fierce conversation, Bola shows his father that nothing can stop him from travelling.

"... Wait a minute," he (Pa Joshua) said. "We need to talk."

... "What is so urgent, Dad? I have to go and meet those who are willing to help me."

Pa Joshua gave the ghost of a smile. "Those who want to help you to flee from your country are not your friends."

"And do you think you are?"

... "Dad, a man must struggle and I am ready to toil."

"Don't toil illegally; if you go underground and begin to work, you will be living like a slave. You will regret. You will suffer. And you will miss many things."

"Look, Daddy," Bola said ironically, "I am ready to suffer; ready to miss many things." (11-4)

Manifestly, the only one way, as for Bola to flee harshness, to secure a good job, work, and live in a good condition is to travel out to USA, to toil, and to suffer as a man and gain his life. Bola sees USA as a promise land, a 
land flowing with milk and honey. He is ensured about the fact that he is not going to toil or suffer to the extent he is toiling at present in his home town.

Continuously, Bola comes back on his issue of migrating to USA. Definitely he is convinced that there is something different and better abroad. Despite his father resistance, he carries the negotiations on, he does not stop the procedure until he gets an opportunity to fulfill and satisfy his desires. Sure of this victory, he engages in a new discussion with his father. Fed up of the living condition, his mother has already been conquered by his ambition and then she gives her approval. He is now looking for ways to gain his father's trust.

"Bola rubbed his hands together fervently and started. "I have been thinking that we could swim out of the present muchy waters. I had the desire long ago and the opportunity has just knocked. You know that I have been processing a visa since last year?"

"Yes, in spite of my objection?"

"Luckily, I have now got the visa. I would like to travel before it expires."' (49)

Bola surely perceives something in this travelling issue because despite his father's warning, resistance, and objection, he does not give up his ambition. He is now trying all his best to convince his father; to tell him that the way is in there. There is no match in his answer to his father's inquiry in the previous quotation. His father is worried and surprised that in spite of his objection, Bola brings that discussion in again. And then he is indirectly asking why? But Bola does not appear to mind the question. This question-answer divergence hides an idea Bola is nurturing. In his answer, by the first word luckily, he is trying to show his father that getting the visa is as a result of good luck; that is to say it is not given to anybody to have such an opportunity. So, indirectly, his father has to forget about his objection old story and take care of the fortune nature offers them. He moves on answering "I would like to travel before it expires" (49). Bola is inviting his father to readiness. His father should not take the obtention of that visa for granted and for an asset, it has a validity period. Bola is telling him it can become invalid. Then, Pa Joshua needs to hurry so that Bola could reach his set goal:

I promise you, Dad. I can buy a land and build a house for the family as soon as I make enough money. You have invested your money on my education so that I can help myself and my siblings. I need your support and cooperation to achieve that objective. I am now an adult; let us collaborate... (52).

Bola is willing to help his father. He is eager to have enough financial resources, as an adult, to take up the assistance of his siblings. He is so obstinate about this idea of travelling that he eventually asks his father to sell 
the only one remaining property of the family to buy the flying ticket in the following speech he has delivered.

I've been trying to raise money for my ticket. But I am not making much headway. I know that Mummy's business has folded up. Meanwhile Yomi and Bridget must go to school. Unfortunately, Government is not forthcoming with your pension and gratuity. Specifically, I know that you have a land property at Keri-Keri. At least, the lands belong to you and you have authority over it. I remember that you often quote a proverb to the effect that those who have access to the hoes shouldn't pick faeces with their bare hands. It is our turn to apply the proverb. Doing so will be killing several birds with one stone. That is why I am suggesting that we sell that piece of land to solve our problems. (49-50)

Bola is expecting his father to get rid of his patrimony to buy a ticket. Through the proverb, he is reminding his father of the saying that goes like use what you have to get what you want. A request that his father has found foolish. "Pa Joshua glared at Bola and turned towards his wife. He expected Julie to interrupt and rebuke the foolish boy" (50).

Contrary to Pa Joshua point of view, I discovered that Bola is right but the only thing he lacks is experience and maturity in decision making. The intention Bola is expressing is proved motivated in the novel under study. The novel reveals several factors that encourage him to stick to his ambition. These factors are of different orders.

Moreover, one of the definitions that reveal there is something in the wind that backs brain drain up is the one suggested by Oxford Advanced Learner's Dictionary of Current English. It is defined as "the movement of highly skilled and qualified people to a country where they can work in better conditions and earn more money" (Hornby, 2010). This definition shows that there are some motives behind this phenomenon. Definitely, there is cause for alarm in the sense that this situation is encouraged by some factors. From the dictionary's definitions it is noticeable that the motives are of two orders: social and economic. But the reasons are also political and ideological in some extent as Ogundimu exposes them in Pensioners and Prisoners.

By the way, the economic reasons mentioned and enlightened by Ogundimu in his novel under study are numerous. Precariousness of living conditions and poverty are an instance of social reasons. It is natural that human nature prefers living comfortably. It longs for financial security, food security, job security, and so on. But once their comfort and well-being are threatened, people usually try by all means to get them secured. At this level, the trend nowadays is that people would choose to leave their hometown. Seeing that they are aware the value of their ability, they decide to go and put 
it into use somewhere else where it is needed. So, today, it is difficult to give the exact number of HSM all over the world. "The exact number of migrant living in Europe is still unknown" (IOM 2005:141).

As Ogundimu shows it, the living condition of the pensioners is precarious. They face real poverty. Most of them live below poverty rate. Pa Joshua $^{23}$ and his whole household are the characters Ogundimu use to depict this situation. Bola has faced real sufferings. His father is a retiree government teacher and he is a graduate from university. Despite that, Bola's living condition is not favorable and comfortable at all. The condition gets so worse that the whole household takes cassava flour with 'kulikuli' cake as breakfast as shown in this passage. "“.... You've had your breakfast; and want to embarrass m..." "If soaking gaari with kulikuli in the morning is what you call breakfast; then I have"' (Ogundimu, 2018:48).

As a pensioner, Pa Joshua has been plunged into despair but Bola refuses to sink into it. Pa Joshua's living condition worsens to the extent that his daughter Bridget has been suspended from school and is not allowed to "write her exams on credit" (48). His son Bola cannot secure a good job then they were all desperate. They live without hope and moreover Pa Joshua is facing an everyday humiliation just like the other pensioners. All the pensioners regularly visit the Ministry of Pensions at the prospect of getting rejoicing news that is to say having their pensions arrears paid. But their plight always increases.

The plight is so critical that even the basic services are not ensured. Pa Joshua cannot afford a transport fair of a six kilometers trip. So, he has to wake up early in the morning, braving and going through darkness as described by the narrator:

Having said their morning prayers, Pa Joshua told his wife that he had to trek to the Pensions Office. Julie did not ask him why; they both know the reason.

Julie opened the door, looked out, paused and cast a doubtful glance back at him. "But it is still dark outside?"

'Yes, but it's almost six o'clock. You know I can't walk in the sun; and Falode to Oke-Mala is about six kilometers. If I get there before the office opens, I shall wait. I stand to lose nothing, if I wait."

"Okay, I wish good luck."

"Thank you darling" (16).

Despite all these disturbances, trials, and visits, nothing has changed. Things are getting worse in each pensioner's household as Pa Joshua said: 'I am not only one in a tight corner. Many of my colleagues are suffering like

${ }^{23}$ Protagonist of Pensioners and Prisoners. A retiree teacher. Eventually, he becomes the leader of the association of pensioners under Governor Awawi 
me. Some are worse off' (42). And to crown it all, Bola shows that they must be the most desperate of all the pensioners. He is supported in his intention by this disastrous living condition of theirs. He says: "I know that Mummy's business has folded up. Meanwhile Yomi and Bridget must go to school. Unfortunately, Government is not forthcoming with your pension and gratuity" (50).

Bola is not motivated only by this harsh economic situation but he is also fed up of some social sickness and realities that appears tolerated in the society under Awawi government. Corruption is in full swing. Civil servants go up to ask a pensioner with more than eight months of non-payment, bribe. They commonly claim that "only those who wet the ground shall step on moistened land" (9). It has been turned into a socially acceptable phenomenon. When Pa Joshua is asked bribe, he shows his opposition against it. But "the woman threw a sarcastic glance almost asking "how do others get it?" She did not put the question openly though; but her look was eloquent enough for him to understand" (8). This question the woman's look is asking means that the previous pensioners "find something for the lady to speed up the process" (19).

Furthermore, Young graduates from universities under Awawi government are unemployed. This is another issue and it constitutes one of the chief reasons Bola tries to convince his father when he is telling Bola to "stay in country and work" (12). "Where are the jobs?" (13), Bola has answered. The situation in the country is revolting. Then, in spite of all the threats his father shows that are awaiting him abroad, Bola prefers to be a slave abroad than be a prisoner at home. (78). "In different time tables the unemployment rate has been $35 \%$ but if we see the unemployment rate among youth, its level at times has even been almost twice as higher that the overall unemployment rate.” (Arifi \& Marmullaku, 2019) In addition, “as a result of the continuous rise in youth employment, this category of society faces problems such as: poverty growth, social exclusion, and a deep economic gap..." (Arifi \& Marmullaku, 2019)

Furthermore, the education system is deteriorating. Through this confession by the Principal of Owolabi College "comparing public schools and private schools is like comparing death with sleep" (46), it appears clearly that education system, especially in public schools contains nothing to be trusted anymore. Pa Joshua says: "I know our education system has gone crumbling" (46). In public schools, things have changed. Public education has already taken a knock.

Politically speaking, government leaders are full of "opportunists", "political jobbers", and crude politicians" (14). They all take advantage of their political and social positions. Those who are not close to the leaders "are locked out of the kitchen" and the mass of the people were driven away from the dining hall" (74). The dining hall symbolizes government institutions, 
income generative activities of the state. So, those who are not directly involved in their management can never be satisfied or attended to.

All these put together, Bola expresses himself while talking to his father as follows:

Now look. I did my First Degree in Business Administration over three years ago. It is now more than two years since I completed my National Youth Service. I cannot go back to school to pursue my studies because there is no money. My father has no means to set me up because his pension is hanging. The states which used and abused my father, has refuse to hire me. For now, my life is suspended, stagnant, being wasted (78-9).

This quotation above clearly brings out the motives that lead Bola to stick to his ambition that is to travel to USA, no matter how the adventure may reveal. In fact, the hard-living conditions blind the youth and make them insensitive and insensible to the risks of adventure. For the youth, life becomes so useless that it is no worthier preserving it. This behavior, in real life, is the confirmation of the fact that though the voyage to Europe through Lampedusa Sea, may be dangerous, perilous and may cost their lives, the African people dedicate themselves to catastrophe which is nothing other than 'Western Paradise'

Thus, Hatton and Williamson have demonstrated some determinants of brain drain. They find out four factors as determinants of migration in general:

- $\quad$ The difference in income across countries.

- $\quad$ The share of population between 15 and 39 years old in the origin and host countries.

- The stock of immigrants.

- The extent of poverty in the country of origin. (Hatton and Williamson 2002)

Finding no other way of getting out of this mess in his own country, Bola has then decided to travel out. Admittedly, the phenomenon of brain drain is favoured by the environment from where the migrants emerge. If there were no problems socially, economically, politically and ideologically, people would not be obstinate about the idea of travelling out to work. These situations in our countries require urgent attention and attendance. Solving them requires the contribution of all. The second axe of this article shows the importance of the coming together of both generations in the quest of better working and living conditions. 


\section{Necessity of connection between Old and Young Generations}

Most of the time, people are used to using the phrase "united we stand, divided we fall" as a motto to inspire cooperation, connection, assistance, collaboration, unity, and so on. In the society, there are two important social strata as far as good governance is concerned: the old generation and the young one. Younger generation is mostly characterised by its inexperience but it also possesses the most needed weapon - strength. Old Generation can also be termed as Experienced Generation. Young people are naïve; they don't care much about political affairs and government issues. 'Conventional 'wisdom' dictates that young people are 'ignorant', 'apathetic', 'selfish', 'indifferent', 'alienated', 'disaffected' and 'disinterested' when it comes to politics', noted Ellen Quintelier (2007). Political issues do not seem to mean a lot to the contemporary young generation. Meanwhile, they are facing challenges, they find themselves in regrettable situations which would be better were the nation run accordingly, they are disinterested. They would rather flee from the nation and go to build other nations. They are aware of the problems but prefer to resign or leave the state on its own and travel out. This exactly what Pa Joshua is resisting when Bola wants to migrate because of unemployment.

Still, this country should be your battlefield. If everybody runs away from the battlefield; who will bring home the spoils of the war? Why would you abandon your country and go to build other nations? Besides, didn't you say that you were a member of Forum for the Unemployed Graduates? What are you doing? Why can't you team up to develop this country? Look here there is a time for everything. This is not a good time for you to travel. Don't let your world fall to pieces (Ogundimu, 2018:13).

It is now clear that these young graduates are conscious of the issue of unemployment. They even form a Forum telling people that there are some unemployed graduates all over the states but without conviction and confidence. If they are aware of the message, they are giving by simply creating a Forum, a member of that forum would never pretend to desert the battlefield and leave the others on their fate. The term 'battlefield' used by $\mathrm{Pa}$ Joshua is making it clear that to solve some socio-political issues, what people need is to fight.

Younger generation, through these utterances by Bola's father, cannot be without guidance. And this unity and connection between generations normally start from households; in a 'parents-children relationship' atmosphere. "The role of family in shaping their children's behavior is very crucial" because "Children from family with strong connection could be in better position about their future life and feel responsible in making decision." (Kumsa, 2015). It is up to the experienced to guide the inexperienced in any 
society. Without being told and revealed the realities they must face, the steps they must follow, and the processes they must enter into and open, the younger generation will be lost or will go astray. Older generation, as said above has the unfailing role to advise and orient the youth to avoid taking immature decisions. In that sense, the intervention of $\mathrm{Pa}$ Joshua later wakes up the youth. They eventually know that they must team up and fight. He always moralises his son Bola:

But you have to learn to be a little patient. There is nothing that has a beginning and does not have an end. This Government has been fumbling too much, it cannot last. No sensible person can be slicing okro and be looking elsewhere. Yet, this is what Governor Awawi is doing. I am sure; something unpleasant will happen. He will slice his finger. Let us stay here and fight the devil together.

How... How do I come in?

There's a lot you can do. Go and meet your friends of the Forum for the Unemployed Graduates. You are all young; you have the needed energy. If you unite, you can move mountains. You will fight for everyone. (96-97).

The question Bola asks proves that he does not know he is concerned with the battle. He is surprised when his father says he should stay so that they can fight together. It is intolerable that the youth wonder how they are concerned with the national fight. This question shows the state of unconsciousness, inexperience, and immaturity of the younger generation.

Fortunately, with the succession of the socio-political blunders and the insistence of $\mathrm{Pa}$ Joshua on the fact that there must be no brain drain, the younger generation eventually realizes the reality about the fact. Faruk, the leader of the Forum says: "Our house is on fire and we cannot afford to go to sleep" ... "many things are going wrong in this state; the pensioners' crisis is getting worse. Our government has gradually become intolerant, aggressive and cold-hearted. Violence is escalating" (119). Definitely, by using the possessive our, it means that the Forum now knows its responsibilities. It is aware of the fact of being part of the 'household'; it must also get involved in the dance, the struggle.

Once the plight of the pensioners is understood by Faruk, the leader, he explains clearly the link between the two paramount misfortunes: unemployment and confiscation of the pensions. He also makes explicit the need to get connected to the old generation so as to get and guarantee a better future for the younger generation when one of his members does not seem to understand.

We are not deviating (from their main objective: fighting unemployment), Banjo. If one cares to think about it properly; 
these things are related; we shall address the two issues. You have to warn your neighbour, when he eats poisonous food. If you don't, his overnight groans will disturb your sleep. I totally agree with you that the problem of graduate unemployment is paramount. That was why we formed the association in the first instance. But, in the same way, the plight of pensioners is crucial. It is the same government killing them that is holding us down. Things cannot stay the way they are currently. Some of us are looking for jobs, we can't get any. Now imagine; those who got the jobs and did well are getting killed by the same state, which employed them. Where does our future lie in a situation like this? Should we keep our fingers crossed? (121)

The issue is that the younger generation is coming to the place of the older one day. So, if they do not get together to resist and find a way out for these socio-political problems, they will, definitely, harvest what they will have sown, as the saying goes.

As for the older generation, there is something to be clarified. "One of the problems the older generation has is the aging problem", according to Jeffers Laurence in his article "The Old to the New Generation". Actually, age is not a problem but an asset. It can only constitute a hindrance when it comes to using physical strength. But, talking about guiding and giving direction, it is very well needed. There is a Yoruba saying stating that ogbon ju agbara lo, which means that it is better to be wise than be rugged ${ }^{24}$. In the same way, Ahmadou Hampaté Bâ (1960) noted that "En Afrique, quand un vieillard meurt, c'est une bibliothèque qui brûle"; an African old man who dies is like a library that burns" 25 . This quotation puts at stake the generational duty.

In effect, contrary to what Laurence said, instead of constituting a problem to the older generation, age rather constitutes a weapon they must put together with the strength of the younger generation to overcome the sociopolitical plight they are going through in the State. Here, lies another reason for the necessity of the connection between the two generations. The contribution of all is required to succeed. The youth are now speaking the same language as PA Joshua. "This fight is not for retirees alone. It is for all of us. It is for the active workers in various unions; and those who understand that injury to one is injury to all", says one of the youth demonstrators (172).

More importantly, each generation make use of different methods, in accordance with their perception of realities, to fight against irresponsibility of the government. It clear that there are different ways of thinking as noted by Jeffers Laurence (n.d.) "My generation definitely has a different way of

${ }^{24}$ My translation.

${ }^{25}$ Trans. Tunji Ogundimu. 
thinking about society compared to the other generation and we have our own way of functioning in society". The younger one starts by sending letter to the government (166-8). Demonstrations follow while the pensioners who are fed up of humiliation and failing promises have recourse to traditional ways to fight (154-9).

Individual fights bring nothing as solution to the plight. The older generation possesses wisdom and knows some technical but archaic ways of solving problem and the younger one has the required strength to implement those strategies; whence the obligation for the two to join hands. As previously quoted from Pa Joshua intervention "you are all young; you have the needed energy. If you unite, you can move mountain. You will fight for everyone" (97). Evidently, with the unification, the unshaken government for several years is shaken. The Governor who always cons and dribbles the pensioners and never wants to get into contact with them is obliged to show himself. And finally, they get a temporary satisfaction through the impeachment of the Governor and his Deputy. In the same way, socio-political blunders, injustice, and inequality can be easily remedied when these two most important social classes come together in the battle.

\section{Commitment seen as sine qua non Condition to Victory.}

Commitment has been defined as the degree of pledging or binding of the individual to a set of behaviors and motivates one to act" (Kiesler 1971). Becker S. Howard (1960) explained that for commitment to come into being, it should be when a person, by making a side bet, links extraneous interests with a consistent line of activity. The concept of commitment is much more sociological issue so it is mostly and widely used or analysed by sociologists. In the society, many a time, people engage whole heartedly in working out some situations. This "consistent line of activity" (Nelson 1957) is accounted for through the usage of the concept by Sociologist as Becker (1960) put it.

Allen \& Meyer (1990) cited in "Defining and Creating Employee Commitment: A review of current research", developed an early model that has received considerable attention. The three-component model they advocated was based on their observation that existing definitions of commitment at that time reflected at least three distinct themes: an affective emotional attachment towards an organisation (Affective Commitment); the recognition of costs associated with leaving an organisation (Continuance Commitment); and a moral obligation to remain with an organisation (Normative Commitment) (Robinson n.d.).

All these conceptions of 'commitment' show, and agree on the fact that the concept includes a kind of attachment to, a determination, and an engagement. It is this kind of engagement that Ogundimu has exposed throughout the novel under study. Commitment is what characterises the 
pensioners and mainly Pa Joshua. It all starts from the day he retires. He shows his commitment in the fight against corruption; in the fight for pensions and gratuity. An elderly, who serves the states and becomes deprived of his rights of retirement. Despite his deplorable and regrettable living condition as shown in the first part of this paper, $\mathrm{Pa}$ Joshua has not been influenced by that situation to tolerate moral blunders. "What I was saying then was that I could not afford fifty thousand Naira" repeats Pa Joshua his second coming to the Pension Office after he has been asked bribe (Ogundimu, 2018:7). "Should I bribe you?" (8), he wonders. But surprisingly, he is in dire need of money. At that time, he can no longer eat his fill, pay his rent; even when he falls sick, he cannot go to hospital because there is no money. He says: "my health has been unstable for the past two and a half months and it is getting worse. I can neither pay hospital bills nor buy prescribed drugs" (67). He could then be vulnerable and do whatever is in his power to get money as early as possible; come what may. But he does not try neither to bribe nor to be corrupted.

Mr Ajegunle, one of the employees of the Ministry of Pension tries to convince him through the devices, vices, and stratagems they are accustomed to. He says: "Is fifty thousand Naira too much? You are going to receive about seven million Naira as gratuity. How much is fifty thousand Naira, considering the huge amount you will claim?" (20). But he answers: "do you realise the gravity of what you are saying? ... How can you open your mouth to say foul things like this? Didn't I work for the gratuity I am about to claim? What are you people turning the civil service to? Don't you receive salaries do you want retirees to borrow money to bribe serving officers?" (20). If one uses the common sense, it is clear that there is logic in what Ajegunle has said. But, as for Pa Joshua, using common sense there will be foolish. He sticks to his sense of loyalty; a good citizen who will not mess about concerning moral values. He will not give his support to such an unwholesome attitude:

Papa Joshua does not stop his sense of commitment on corruption. He shows himself so committed in the fight against Governor Awawi as other pensioners do. If not for commitment, those old pensioners will not be defying rain or sun all the time they must get to the Ministry at Oke- Mala (7). And eventually, when they become fed up of the "same old story", they decide to either collect their pension by force or impeach Governor Awawi or even make him resign (171).

The government is obliged to commit atrocities to discourage them, but they are not discouraged. The officers, guards in the Ministry shot the pensioners. At the first atrocious event, four demonstrators lose their lives (115). Despite this, pensioners do not give up. Some of them have been captured and put into jail; all the same they do not abandon the battle. They are abandoned to their fate, not willing to discuss with them; they are illtreated, still they keep on fighting (107-11). Definitely, commitment affects 
people. Once it opens their eyes on the interests (general or individual) of the outcome of the battle, they become obsessed and ready than ever to fight. Through the succession of these events, it is clear that all the demonstrators are psychologically affected.

Finally, the House of Assembly which has previously been accused of being in complicity with the Executive reacts and impeach Governor Awawi to the joy of the pensioners (189-91). They, eventually, win the battle. It must not be forgotten that the key element that play a paramount role in the victory of the citizen is commitment. Everyone engaged in the battle shows how committed they are. For any project or ambition to be successful, commitment cannot be put aside.

\section{Conclusion}

Brain drain has an important growing rate all over Africa. It appears difficult to control or stop according to the aforementioned figures about it in the last three decades. And what is rendering it hard or a problem is that Africa disposes some home determinants that favour it socially, economically, politically, religiously, and ideologically. Still, this paper shows that the best option in the quest for solution is not brain drain, at all. It has also been revealed in the article that the problem is that the younger generation is immature and takes decisions prematurely. They then need to be oriented by the older generation. At the end of this study, it appears clearly that when the old generation uses its experiences to oppose the brain drain and eventually help the younger generation get all its senses and engage in the national battle. So, the study shows that there is a necessity of connection between the two generations. Age is then not a problem old generation as Laurence stated in the discussion above. Instead, it is an asset.

Another important outcome of this study, as this paper argues, is that no serious and important task can be carried out if the one carrying out the task is not committed to do it. In whatever necessary battle one is engaged, one needs compulsorily to be committed to the task for its success. In this study, the analysis has proved that commitment is the very important step that leads to victory; surely, it is.

\section{References:}

1. Allen, N. Meyer, J. (1990). "The measurement and antecedents of affective, continuance, and normative commitment to the organisation". Journal of Occupational Psychology, Vol. 63, pp. 1-18

2. Arifi A. \& Marmullaku B. (2019). "Youth Labor Market Transition Challenges in Western Balkans: The Case of Macedonia, Serbia; and Montenegro", European Scientific Journal, vol. 15 No. 5, pp. 154-5. 
3. Becker S. Howard (1960). "Notes on the Concept of Commitment". The American Journal of Sociology, 66.1: pp. 32-40.

4. Castro, Fidel. Ramonet, Ignacio (Interviewer) (2009). My Life: A spoken autobiography. New York: Scribner.

5. Docquier, F. and S. Khalid. (2006). "The Brain Drain: What Do We Know?" Agence Française de Développement.

6. Dugger, Celia, W. (Oct. 25, 2005). "Study Finds Small Developing Lands Hit Hardest by 'Brain Drain'”. New York Times: New York N.Y. p.9.

7. Grubel, Herbert, G. and Anthony Scott (1977). "The Brain Drain: Determinants, Measurements and Welfare Effects. Ontario, Canada: Wilfrid Laurier University Press.

8. Haque, N. U. And A. Jahangir (1999). "The Quality of Governance: Second Generation Civil Reform in Africa", Journal of African Economies 8, pp. 65-106

9. Hart, David M. (2006). "From Brain Drain to Mutual Gain: Sharing the Benefits of High-Skill Migration. Issues in Science and Technology, Fall. Issues in Science and Technology.

10. Hatton, T. J. And J. G. Williamson (2002). "What Fundamentals Drive World Migration?", NBER Working Paper N 9159.

11. Hornby, A. S. (2010). Oxford Advanced Learner's Dictionary of Current English. Ed. Joanna Turnbull et al. $8^{\text {th }}$ edition. Oxford: Oxford University Press.

12. IOM (2005). World Migration Report - Costs and Benefits of International Migration, International Organization for Migration, Geneva.

13. Jeffers, Laurence (n.d). "The Old to the New Generation".

14. Kiesler, C.A. (1971). The psychology of commitment: Experiments linking behavior to belief. San Diego, CA : Academic Press.

15. Kumsa, D. M. (2015). "Factors Affecting the Sexual Behavior of Youth and Adolescent in Jimma Town, Ethiopia”, European Scientific Journal, vol. 11 No. 32, p. 91

16. Kweitsu, Richard. (2018). "Brain Drain: a Bane to Africa's Potential. Mo Ibrahim Foundation.

Last edited on 7 August 2019, at 07:22

17. Marxism - Wikipedia, https://en.m.wikipedia.org/wiki/Marxism

18. Nelson, N. Foote. (1937). "Concept and Method in the Study of Human Development". Emerging Problems in Social Psychology, ed. Muzafer Sherif and M. Wilson (Norman, Okla.: Institute of Group Relations, pp. 29-53.

19. Ogbuagu, B. C. \& Baffoe M. (2015). "Stuck in the Middle of Nowhere? Deconstruction and Reconstruction of Identities among 1.5 
Generation African Migrant Youth in the North American Societies: Dilemmas and Challenges", European Scientific Journal, vol. 11 No. 17, p. 18.

20. Ogundimu S. Tunji (2018). Pensioners and Prisoners, Abeokuta: Campus Publications Ltd.

21. Quintelier, Ellen (2007). "Differences in political participation between young and old people" Routledge Taylor \& Francis Group: Belgium Contemporary Politics, 13.2.

22. Robinson, Dilys (n.d.). "Defining and Creating Employee Commitment: A review of current research".

23. Working out of Poverty (2003). Report of the $91^{\text {st }}$ International Labour Conference. 